\title{
Cijena neodmjerenoga investiranja. Uzroci i posljedice štrajka u riječkoj luci 1969. godine
}

\author{
IVANA DOBRIVOJEVIĆ TOMIĆ \\ Institut za savremenu istoriju \\ Beograd, Srbija \\ ivanadobrivojevic@hotmail.com
}

\begin{abstract}
Tema rada je veliki štrajk u riječkoj luci koji je izbio u lipnju 1969. godine. Iako je taj, na momente i nasilan, izljev radničkoga nezadovoljstva iznenadio i uznemirio partijski vrh, u historiografiji je ta epizoda ostala gotovo nepoznata. U radu ćemo analizirati uzroke štrajka, njegove posljedice i reakcije koje je izazvao u državnom rukovodstvu. Korišteni su izvori iz Arhiva Jugoslavije, kao i relevantna periodika i literatura.
\end{abstract}

Ključne riječi: štrajk; riječka luka; 1969.; Jugoslavija; Savez komunista Jugoslavije

\section{Uvod}

Društveni položaj radnika u socijalističkoj Jugoslaviji važna je, ali od 80 -ih godina prošloga stoljeća relativno zanemarena historiografska tema. Usprkos velikim socijalnim razlikama među društvenim slojevima, relativno niskom životnom standardu i otvorenom iskazivanju nezadovoljstva, bilo štrajkovima ili predstavkama visokim partijskim funkcionarima, o čemu svjedoče brojni izvori koji se čuvaju u Arhivu Jugoslavije, svakodnevica i problemi radnika kao klase relativno su rijetko obrađivani. Međutim, usporedno s porastom interesa za povijest rada u zapadnoeuropskim historiografijama rastao je i interes za povijest radništva u socijalizmu na postjugoslavenskom prostoru. Posljednjih desetak godina pojavili su se radovi koji tretiraju probleme vezane za radnike kao klasu, radna prava i radničko samoupravljanje, društvene nejednakosti i svojevrsnu stambenu segregaciju, osobito izraženu od početka 60 -ih godina. Ovom prilikom spomenut ćemo radove Gorana Musića, Vladimira Unkovskog-Korice, Slobodana Selinića, Predraga J. Markovića, Nade Novaković, Josipa Mihaljevića, Zdenka Radelića i Roryja Archera. Pri pisanju članka, osim navedenih, od posebne su nam koristi bili stariji radovi Nece Jovanova i sociologa Nebojše Popova i Josipa Županova.

Obrađujući uzroke i posljedice velikoga štrajka u riječkoj luci, oslanjali smo se prvenstveno na arhivsku građu - fondove Centralnoga komiteta Sa- 
veza komunista Jugoslavije, Saveznoga izvršnog vijeća i Kabineta predsjednika koji se čuvaju u Arhivu Jugoslavije u Beogradu, relevantnu periodiku i literaturu. Smatrajući da nema izolirane, nepovezane i „odsječene” prošlosti, nastojali smo uzroke i posljedice toga štrajka staviti u širi jugoslavenski i hrvatski društveno-ekonomski kontekst. Koji su bili uzroci i posljedice štrajka u riječkoj luci? Kako su vlasti reagirale na štrajk? Do koje su mjere neracionalne investicije, neprestana pomoć gubitaškim poduzećima i izbjegavanje otpuštanja viška radne snage, gledano na duge staze, stvarali gotovo nerješive socijalne probleme? To su neka od ključnih istraživačkih pitanja na koja ćemo pokušati odgovoriti u radu.

Sukob sa Sovjetskim Savezom i (vanjsko)političko prestrojavanje Jugoslavije doveli su do relativne liberalizacije i demokratizacije društva. Promjene su se, počevši od sredine 50-ih godina prošloga stoljeća, osjetile i u privredi. Forsiranje teške industrije na račun ostalih sektora ekonomije je napušteno, povećana su izdvajanja za poljoprivredu, ulagalo se u proizvodnju robe široke potrošnje i u razvoj infrastrukture. ${ }^{1}$ Mini privredna reforma iz 1961. dodatno je smanjila utjecaj države u privredi, ali i otvorila put bržem raslojavanju društva. Iako je liberalizacija ekonomskih prilika bila neminovnost, propadanje neuspješnih poduzeća, otpuštanje suvišnih radnika i rastuća inflacija najviše su pogađali najsiromašnije slojeve stanovništva. Nezadovoljstvo je raslo, a radnici su se najviše žalili na plaće, teške stambene prilike i nisku kupovnu moć. Neposredno pred privrednu reformu (1965.)² Jugoslaveni su pravili zalihe robe ${ }^{3}$ i otvoreno govorili da je "dinar izgubio svaku vrednost”. ${ }^{4}$ Reforma je omogućila suzbijanje inflacije, standard je ponovo počeo rasti 1966. postupno se smanjivao udio najnižih plaća u ukupnoj masi zarada, izdaci za prehranu su opadali, a iznosi štednih uloga premašivali su iznose zaduženja po potrošačkim kreditima. ${ }^{5}$

Pokazalo se međutim da su rezultati privredne reforme ipak bili skromni. Konjunkturu viđenu krajem 50-ih godina bilo je nemoguće ponoviti, a nezaposlenost je postajala sve veći društveni problem. Štoviše, ukidanje administrativnoga načina upravljanja privredom donijelo je nova iskušenja. Poduzeća nenavikla na nove, tržišne uvjete poslovanja zapadala su u bezizlazne ekonomske teškoće. Proizvodnja je povećavana bez obzira na potražnju, roba je gomilana u skladištima, gubici su rasli, a plaće kasnile. Pribojavajući se so-

1 SR-AJ-142/1-15-41, Stenografske beleške sa sednice Predsedništva saveznog odbora SSRNJ-a održane 21. 11. 1956. Izlaganje Mijalka Todorovića; HORVAT, Privredni sistem i ekonomska politika Jugoslavije, 29. Vidi: DOBRIVOJEVIĆ TOMIĆ, „Harbingers of Crisis. Labor Strikes in Yugoslavia (1958-1974)", 162.

2 Vidi: BILANDŽIĆ, Historija Socijalističke Federativne Republike Jugoslavije, 305-319.

3 SR-AJ-837-KPR, II-3-a-2/133, Informacije o reagovanjima građana u sarajevskom srezu na povećanje cena i stav komunista (13. 2. 1965.); SR-AJ-837-KPR, II-3-a-2/139, Informacije o reagovanjima građana u Vojvodini i novosadskom srezu na povećanje cena (8. - 17. 3. 1965.).

4 SR-AJ-837-KPR, II-3-a-2/139, Informacije o reagovanjima građana u Vojvodini i novosadskom srezu na povećanje cena (8. - 17. 3. 1965.).

5 SR-AJ-507-CK SKJ, IV, k3/6, Neka pitanja razvoja životnog standarda (1968.). 
cijalnih implikacija, vlasti su išle linijom manjega otpora, održavajući nekako likvidnost pomoću kredita ili pak prelijevanjem sredstava iz poduzeća koja su dobro poslovala. Socijalno raslojavanje dobivalo je na ubrzanju: 1968. godine oko 40\% radnika zarađivalo je manje od 600 dinara mjesečno ${ }^{6}$, a visokorangirani službenici i intelektualci imali su, za socijalističke prilike, relativno visoke zarade. Društvo je sve više postajalo potrošačko, robe je bilo sve više, a posjedovanje tehničkih uređaja, nešto kasnije i automobila, polako je postajalo san gotovo svakoga Jugoslavena, ali i neka vrsta statusnoga simbola. ${ }^{7} \mathrm{O}$ svojevrsnom socijalnom preuređivanju do gotovo monolitnoga socijalističkog društva svjedočio je i raspon između najniže i najviše zarade, koji je dostigao odnos 1 : 10. Uslijed velikoga raspona plaća sve više se diferencirala i razina osobnoga standarda radnika istih ili približnih kvalifikacija ovisno o tome u kojoj su grani, grupaciji ili poduzeću radili. Tako stvorene razlike postale su motiv „za razna reagiranja i nezadovoljstva”, koja su bila potencirana i bržim porastom zarada u izvanprivrednim djelatnostima. Ni službeni partijski izvještaji nisu prikrivali težak materijalni položaj većine radnika u proizvodnji, ističući da „relativno veliki broj zaposlenih, naročito u radno intenzivnim granama, ostvaruje minimalne odnosno niske lične dohotke”. Iznevjerena očekivanja dijelova stanovništva stvarala su atmosferu u kojoj su štrajkovi, u to vrijeme eufemistički nazivani „obustavama rada” i „konfliktnim situacijama”, postali jedno od glavnih sredstava pritiska radnika nezadovoljnih svojim materijalnim položajem na vlasti. ${ }^{8}$

\section{Radnički štrajkovi: izraz nezadovoljstva i sredstvo pritiska na vlast}

Od prvoga štrajka u rudniku Trbovlje (siječanj 1958. ${ }^{9}$ do sredine 1969. u Jugoslaviji je, prema nepotpunoj statistici, organizirano ukupno 1800 štrajkova, u kojima je sudjelovalo oko sto tisuća radnika. ${ }^{10}$ Štrajkaši su, gotovo po pravilu, bili radnici u proizvodnji, a obično je rad obustavljao samo jedan dio

6600 dinara bila je minimalna prosječna zarada u najslabije plaćenim industrijskim granama; SR-AJ-507-CK SKJ, IV, k3/6, Neka pitanja razvoja životnog standarda (1968.).

DOBRIVOJEVIĆ TOMIĆ, „Harbingers of Crisis. Labor Strikes in Yugoslavia (19581974)”, 163-165. Vidi i: DUDA, „Tehnika narodu! Trajna dobra, potrošnja i slobodno vrijeme u socijalističkoj Hrvatskoj", 375; MARKOVIĆ, Beograd između Istoka i Zapada, 313-315; HYDER, Bought and Sold, 34; LUTHAR, „Remembering socialism: On desire, consumption and surveillance", 230-234.

8 DOBRIVOJEVIĆ TOMIĆ, „Harbingers of Crisis. Labor Strikes in Yugoslavia (19581974)", 164-165.

9 POPOV, „Štrajkovi u savremenom jugoslovenskom društvu”, 608-609; UNKOVSKI-KORICA, The Economic Struggle for Power in Tito's Yugoslavia, 167-170; MIHALJEVIĆ, Komunizam i čovjek, 283-284. Iako je štrajkova bilo još 1945., smatrali smo da je štrajk u Trbovlju prvi veliki štrajk u socijalističkoj Jugoslaviji. O štrajkovima neposredno po oslobođenju vidi: RADELIĆ, „Prvi štrajkovi u socijalističkoj Jugoslaviji (Dokumenti iz 1945. godine)”, 123 139.

10 SR-AJ-507-CK SKJ, III/142, Stenografske beleške sa VI sednice Predsedništva SKJ od 17. 11. 1969 . 
kolektiva. Stagnacija zarada u mnogim poduzećima, rast cijena namirnica i poskupljenje usluga dovodili su najsiromašnije društvene slojeve tijekom 60ih godina na sam rub egzistencije. ${ }^{11}$ Nagomilane privredne teškoće koje su godinama opterećivale čitave privredne grane i zaposlene u njima nije bilo jednostavno riješiti. Nedovoljna prilagođenost potrebama tržišta, nepotpuno korištenje postojećih kapaciteta, zastarjela tehnologija i slaba tehnička opremljenost, loša kvalifikacijska struktura zaposlenih, velika izdvajanja za plaće i lakomisleno uzimanje kredita bili su samo neki od problema s kojima su se suočavala slabo rentabilna jugoslavenska poduzeća. Nelikvidnost se rješavala prebijanjem dugova i potraživanja, ali i specifičnom kreditnom politikom političkoga rukovodstva i poslovnih banaka, koje su često koristile sredstva rentabilnih poduzeća ne bi li pomogle gubitašima. ${ }^{12}$ Prestrukturiranje proizvodnje u pojedinim granama išlo je sporo i teško, a o stupnju zaostajanja $\mathrm{i}$ nekonkurentnosti jugoslavenske ekonomije krajem 60-ih godina najrječitije svjedoči podatak da je čak 27\% svih Jugoslavena zaposlenih u društvenom sektoru radilo u poduzećima koja su poslovala na rubu rentabilnosti ili s gubitkom. ${ }^{13}$ Štoviše, na temelju „opravdanih pretpostavki” smatralo se da gubici navedeni u završnim računima poduzeća „ne odražavaju pravo stanje”, nego su veći od onih prikazanih. ${ }^{14}$ Dio privrede koji je nerentabilno poslovao bio je „permanentan izvor pritisaka na reformu” budući da su neprestano bili u poziciji da „dele i koriste sredstva prelivena od drugih”, „posluju van reformskih okvira”, „raspodeljuju van rezultata rada” i „vrše razne pritiske u ime radnika". ${ }^{15}$ Posebno teška situacija vladala je u poduzećima tekstilne, kožne i drvne industrije, kao i u rudnicima za proizvodnju ugljena. Nagomilane ekonomske probleme bez velikih rezova nije bilo moguće riješiti. Sindikat je imao čvrsto stajalište da rekonstrukciju poduzeća i modernizaciju proizvodnje treba ubrzati, ali se „u praksi držati stava da nitko ne može ostati bez posla” da se ne bi stvarala nesigurnost kod radnika i izazivao otpor prema osuvremenjivanju poslovanja. $^{16}$

Pokušaji konsolidacije neuspješnih poduzeća podrazumijevali su ukidanje dijela stečenih radnih prava, često mimo znanja i volje zaposlenih. U poduzećima koja su godinama tavorila na rubu egzistencije revoltirani su radnici i na same nagovještaje smanjivanja izdataka koji su dolazili od uprave odgovarali prekidom rada. Neposredni povodi štrajkova sličili su jedan drugom. Prosvje-

11 SR-AJ-507-CK SKJ, III/141, Stenografske beleške sa V sednice Predsedništva SKJ od 14. 10. 1969.

12 SR-AJ-507-CK SKJ, III/141, Problemi nelikvidnosti u jugoslovenskoj privredi (16. 9. 1969.).

13 SR-AJ- A CK SKJ, III/141, Stenografske beleške sa V sednice Predsedništva SKJ od 14. 10. 1969.

14 SR-AJ-507-CK SKJ, III/141, Problemi nelikvidnosti u jugoslovenskoj privredi (16. 9. 1969.).

15 SR-AJ-507- CK SKJ, III/141, Stenografske beleške sa V sednice Predsedništva SKJ od 14. 10. 1969.

16 Isto. 
dovalo se protiv smanjivanja i neredovitoga isplaćivanja plaće, povećavanja norme, umanjivanja godišnjega odmora i regresa za dane odmora, pooštravanja uvjeta za korištenje bolovanja, ukidanja ili umanjivanja naknade za prijevoz na rad i prehranu, otpuštanja radnika iz proizvodnje kao tehnološkoga viška, ali i iz uvjerenja da su radnički savjeti samo dekor budući da najvažnije odluke donose uprave poduzeća. ${ }^{17} \mathrm{U}$ obrani onoga što se smatralo temeljnim radnim pravima, ali i socijalističkoga sistema u idealnom obliku ${ }^{18}$, sudjelovali su radnici svih razina obrazovanja, članovi Saveza komunista i članovi radničkih savjeta. ${ }^{19}$ Prema mišljenju sociologa Josipa Županova, okosnicu štrajkova činila je „neformalna organizacija radnika” koja je bila ograničene veličine, stoga su štrajkovi u jugoslavenskim poduzećima rijetko izlazili iz okvira jedne radionice ili pogona. ${ }^{20}$ Narastajuće nezadovoljstvo među radnicima partijske i sindikalne organizacije u poduzećima nisu umjele ni kanalizirati ni suzbiti. Sudeći prema raspoloživim izvorima, sindikalni aktivisti obično su bili na repu događaja budući da radnici prije prekida rada nisu ni pokušavali riješiti nagomilane probleme preko sindikata. ${ }^{21}$ Ništa uspješnije u anticipiranju teškoća nisu bile ni partijske organizacije po poduzećima. Iako se od članova Partije očekivalo da stvore „takve uslove i takvu situaciju” da do štrajkova i ne dođe $^{22}$, o stupnju njihova nesnalaženja rječito je govorila i tvrdnja Mike Tripala, člana Izvršnoga biroa Predsjedništva Saveza komunista Jugoslavije, da se Savez komunista „raspao u mnogim organizacijama” u kojima su štrajkovi duže trajali. ${ }^{23}$ Međutim, iako su štrajkovi u jugoslavenskom socijalizmu bili usmjereni „na rešavanje trenutnih problema”, oni su, zajedno s ekonomskim migracijama na Zapad, bili „značajan ventil za ispuštanje pare” ${ }^{24}$, tj. kanaliziranje i oslobađanje dijela radničkoga nezadovoljstva.

Sve izraženija liberalizacija prilika u zemlji, ali i veća učestalost štrajkova, utjecala je na to da partijski vrh napusti stajalište da je „svaka obustava rada neprijateljska" i da se njome trebaju baviti organi državne sigurnosti. ${ }^{25}$ Od 60-ih godina na štrajkove se, prema ocjeni Krste Crvenkovskog, počelo

17 DOBRIVOJEVIĆ TOMIĆ, „Harbingers of Crisis. Labor Strikes in Yugoslavia (19581974)", 170-171.

18 SR-AJ-837-KPR, II-3-c-2/64, Informacije sa sednice Predsedništva Veća SSJ održane 7. 10. 1969.

19 SR-AJ-837-KPR, II-3-c/64, Konfliktne situacije u radnim organizacijama i način njihovog rešavanja (15. 9. 1969.); ARZENŠEK, „Otuđenje i štrajk”, 6-7.

20 ŽUPANOV, „Industrijski konflikti i samoupravni sistem”, 18.

${ }^{21}$ SR-AJ-507- CK SKJ, IV/75, Stenografske beleške sa 13. sednice Izvršnog biroa Predsedništva SKJ održane 1. 7. 1969.

22 SR-AJ-507-CK SKJ, III/143, Stenografske beleške sa VII sednice Predsedništva SKJ od 15. 12. 1969. u Zagrebu.

${ }^{23}$ SR-AJ-507-CK SKJ, III/142, Stenografske beleške sa VI sednice Predsedništva SKJ od 17. 11. 1969.

24 ŽUPANOV, „Industrijski konflikti i samoupravni sistem”, 21, 24.

25 SR-AJ-837-KPR, II-3-c/64, Konfliktne situacije u radnim organizacijama i način njihovog rešavanja (15. 9. 1969.). 
gledati „mirnije i razložnije”. ${ }^{26}$ Prihvaćeni su kao sastavni dio svakodnevice, toliko uobičajen da je i tisak o njima naširoko i blagonaklono izvještavao. ${ }^{27}$ Iako jedinstvenoga službenog stava o ovom pitanju nije bilo ${ }^{28}$, po mišljenjima partijskoga i državnoga rukovodstva koja su se čula na brojnim sjednicama i savjetovanjima, uzroke tih epizoda trebalo je tražiti, osim u niskim zaradama dijela radnika, i u „birokratskoj samovolji, uzurpaciji i raznim tehnokratskim manipulacijama”. Iznesena teza bila je na tragu Titovih uvjerenja da „štrajkovi u našoj zemlji... se ne mogu upoređivati sa štrajkovima u kapitalističkom sistemu gde se radnici bore za povećanje nadnica i bolje uslove života”. U Jugoslaviji pak radnici-samoupravljači obustavljaju rad negodujući „zbog nepravilnog odnosa pojedinih rukovodećih ljudi u poduzeću” i njihove „tvrdoglavosti”. ${ }^{29}$ Iako se priznavalo da su „u obustavama rada ponekad izražavani neopravdani zahtevi”, „nastali kao rezultat demagogije, pa čak i neprijateljskog rada”, u partijskom i državnom vrhu smatrali su da se treba „osloboditi iluzije o socijalističkom društvu bez konflikata” i tumačili štrajkove kao izraz „porasta svesti radničke klase o sopstvenoj društvenoj ulozi”. ${ }^{30}$ Štoviše, Miloš Minić, Veljko Vlahović i Vladimir Bakarićc ${ }^{31}$ priznavali su 1965. i 1966., kako navodi Predrag Marković, radnicima da se na taj način „bore protiv birokratskih deformacija”. ${ }^{32}$ Krajem 1969. Partija je zauzela stav da se njezini članovi, kao i članovi Saveza sindikata, „moraju energično suprotstaviti pritiscima svake vrste za rešavanje problema i teškoća van samoupravnih struktura” budući da obustave rada „narušavaju samoupravni sistem”, „eliminišu konstruktivni dijalog” i koče „samoupravno i ekonomsko kretanje društva”. ${ }^{33}$

26 SR-AJ-507-CK SKJ, III/142, Stenografske beleške sa VI sednice Predsedništva SKJ od 17. 11. 1969.

27 Isto; SR-AJ-837-KPR, II-3-c-2/64, Štampa o obustavama rada u Jugoslaviji (1969.); „Štrajk i samoupravljanje”, Borba (Beograd), 27. 9. 1969.

28 SR-AJ-837-KPR, II-3-c/64, Konfliktne situacije u radnim organizacijama i način njihovog rešavanja (15. 9. 1969.).

29 SR-AJ-507-CK SKJ, III/142, Stenografske beleške sa VI sednice Predsedništva SKJ od 17. 11. 1969.

30 SR-AJ-837-KPR, II-3-c-2/64, Informacije sa sednice Predsedništva Veća SSJ održane 7. 10. 1969.

31 U spomenutom periodu Miloš Minić obavljao je funkciju potpredsjednika Saveznoga izvršnog vijeća, Veljko Vlahović bio je član Izvršnoga komiteta i član Predsjedništva Socijalističkoga saveza radnog naroda Jugoslavije, a Vladimir Bakarić bio je sekretar Centralnoga komiteta Saveza komunista Hrvatske i član Predsjedništva Centralnoga komiteta Saveza komunista Jugoslavije.

32 MARKOVIĆ, „Radnički štrajkovi u socijalističkom i tranzicionom društvu Jugoslavije i Srbije", 55-56.

33 SR-AJ-837-KPR, II-3-c-2/64, Predlog zaključaka o konfliktnim situacijama i načinu njihovog razrešavanja (18. 9. 1969.). Zaključci su prihvaćeni 26. lipnja 1970. Vidi i: DOBRIVOJEVIĆ TOMIĆ, „Harbingers of Crisis. Labor Strikes in Yugoslavia (1958-1974)”, 168. Kako je Jugoslavija bila potpisnica Međunarodnoga pakta o ekonomskim, socijalnim i kulturnim pravima, koji je jamčio pravo na prosvjedni prekid rada u skladu sa zakonima svake zemlje, Savezni pravni savjet zatražio je u srpnju 1973. od Vijeća Saveza sindikata da pošalju predstavnika na sjednicu na kojoj će se razgovarati o potrebi da se u nacrt Ustava unese pravo na štrajk. Dragoslav Mišić, sekretar Vijeća, na sjednici je obrazložio stav da štrajk ne bi trebao 
Iako su štrajkovi organizirani prije svega u onim privrednim granama koje su imale teže uvjete privređivanja, protestnoga prekida rada bilo je i u poduzećima koja su relativno dobro stajala. Nezadovoljstvo se iz proizvodnje prenosilo i na javni sektor, pa su bilježeni štrajkovi u osnovnim i srednjim školama, sudstvu i zdravstvu. ${ }^{34} \mathrm{Na}$ štrajkove su, prema raspoloživim izvorima, uglavnom bili „imuni” zaposleni u financijskom sektoru, vanjskotrgovinskim poduzećima i trgovini. ${ }^{35}$ Štrajkovi su s vremenom dobivali na intenzitetu i odlučnosti, formirani su štrajkaški odbori, a radnici su, osobito od sredine 60-ih godina, sve češće izlazili demonstrirati izvan kruga poduzeća, pokušavajući tako nagomilanim socijalnim problemima dati širi politički karakter. ${ }^{36}$ Izlazak štrajkaša na ulice uznemirivao je državni vrh jer je i u relativno liberaliziranim društvenim okolnostima i dalje prevladavalo mišljenje da je „podsticanje na siledžijstvo, demonstriranje i izazivanje nereda” rezultat aktivnosti „neprijateljskih elemenata”. ${ }^{37}$ Premda je milicija veoma rijetko intervenirala, organi unutarnjih poslova ipak su prikupljali informacije o štrajkovima i vodili svoju, doduše šturu, evidenciju o tim izljevima radničkoga nezadovoljstva. ${ }^{38}$

Do 1969. prekidi rada u jugoslavenskim poduzećima odvijali su se po više-manje ustaljenoj dinamici. Obično su u štrajk stupali radnici samo jednoga dijela poduzeća, proizvodni proces prekidan je na tek nekoliko sati, a štrajkašima se izlazilo ususret u najkraćem mogućem roku. Štrajkovi kao oblik pritiska na vlasti davali su rezultate, a svi oni problemi na koje se upozoravalo više mjeseci ekspresno su se rješavali. I sami direktori poduzeća bili su svjesni popustljivosti lokalnih, republičkih i državnih organa, pa su delegacije nezadovoljnih radnika savjetovali da se izravno žale višim instancama. Ta praksa bila je do te mjere rasprostranjena da je čak i u jednom od izvještaja lakonski konstatirano da ponekad „tehnokratskim i birokratskim strukturama radnih organizacija odgovara da dođe do obustave rada” ne bi li na taj način vršili pritisak na više instance, „čak i onda kad su nepovoljni rezultati poslovanja rezultat njihove nesposobnosti". ${ }^{39}$

postati ustavno pravo s obzirom na to da u Jugoslaviji radnici, kao samoupravljači, o svim bitnim pitanjima odlučuju neposredno. JOVANOV, Radnički štrajkovi u SFRJ od 1958. do 1969., 39-40.

34 DOBRIVOJEVIĆ TOMIĆ, „Harbingers of Crisis. Labor Strikes in Yugoslavia (19581974)", 170.

35 SR-AJ-507- CK SKJ, III/142, Stenografske beleške sa VI sednice Predsedništva SKJ od 17. 11. 1969.

36 DOBRIVOJEVIĆ TOMIĆ, „Harbingers of Crisis. Labor Strikes in Yugoslavia (19581974)", 170.

37 SR-AJ-837-KPR, II-3-c/64, Konfliktne situacije u radnim organizacijama i način njihovog rešavanja (15. 9. 1969.).

38 SR-AJ-507- CK SKJ, IV/75, Stenografske beleške sa 13. sednice Izvršnog biroa Predsedništva SKJ održane 1. 7. 1969.

39 DOBRIVOJEVIĆ TOMIĆ, „Harbingers of Crisis. Labor Strikes in Yugoslavia (19581974)”, 167; SR-AJ- 117-73-170, Nezadovoljstvo radnika i službenika i neke druge pojave u Jugoslovenskim železnicama. (Izvještaj je rezultat provjere koju su obavila odjeljenja saveznoga 


\section{Bunt u riječkoj luci}

Zahtjevi za sitnije materijalne ustupke koji su bili neposredan povod većine štrajkova maskirali su dublje probleme i nezadovoljstvo radnika vlastitim društveno-ekonomskim položajem. Financijske teškoće u kojima su se nalazili zaposleni uslijed kašnjenja plaća stvarale su u pojedinim poduzećima svojevrsnu „psihozu nezadovoljstva”. ${ }^{40}$ Poseban revolt izazivali su kriteriji za raspodjelu osobnih dohodaka po kojima su radnici isplaćivani u skladu s rezultatima rada, a ostali su, osobito prateće administrativne službe, imali fiksnu zaradu. ${ }^{41}$ Loš socijalno-ekonomski položaj radnika, posebno nekvalificiranih i polukvalificiranih, utjecao je i na međuljudske odnose. Podvojenost između radnika i službenika je rasla ${ }^{42}$, a poštovanje prema članovima Partije u nekim poduzećima, na primjer u beogradskoj Industriji motora Rakovica, opadalo je jer su ih radnici smatrali „oportunistima”. ${ }^{43}$ U prvoj polovini 1969. Jugoslaviju su potresla tri velika štrajka koja se, prema ocjeni Kire Gligorova, „nisu mogla izjednačiti sa onim pojavama ranije, povremenim obustavama rada iz konkretnih razloga koji su često puta bili vezani za samo preduzeće". ${ }^{44}$ Postalo je jasno da protesti u željezari Jesenice (travanj), Industriji motora u Rakovici (svibanj) i riječkoj luci (lipanj) mogu imati šire socijalno-političke implikacije. Te tri epizode iznenadile su i duboko uznemirile jugoslavensko rukovodstvo. Svjesni da su obustave rada prvi put bile praćene demoliranjem strojeva ${ }^{45}$ i fizičkim nasiljem relativno ograničenoga obima ${ }^{46}$, jugoslavenski funkcionari nisu se libili stvari nazvati pravim imenom. Mijalko Todorović, član Predsjedništva Saveza komunista Jugoslavije, smatrao je da je štrajk u riječkoj luci, zajedno sa studentskim demonstracijama i protestom Albanaca na Kosovu, jedan od "tri ozbiljnija potresa koja smo imali u poslednje vreme”, a Tito je taj izljev radničkoga nezadovoljstva jednostavno okarakterizirao kao "pobunu". 47

Neposredni povod za štrajk bile su sanacijske mjere donesene krajem 1968. budući da se poduzeće „Luka” još od veljače 1967. hrvalo s financijskim problemima. ${ }^{48}$ Manji štrajkovi u riječkoj luci organizirani krajem 1968. doveli

i republičkih državnih sekretarijata za unutarnje poslove.) Vidi i: SR-AJ-837-KPR, II-3-c-2/28, Informacija o obustavama rada za period 1958 - prvo polugođe 1964.

40 MUSIĆ, Making and Breaking the Yugoslav Working Class, 45.

41 „Štrajk i samoupravljanje”, Borba, 27. 9. 1969.

42 SR-AJ-837-KPR, II-3-a-2/46, Izveštaj Vlajka Begovića od 19. februara 1964.

43 MUSIĆ, Making and Breaking the Yugoslav Working Class, 44.

${ }_{44}$ SR-AJ-507-CK SKJ, IV/73, Stenografske beleške sa 11. sednice Izvršnog biroa Predsedništva SKJ održane 15. 6. 1969.

45 Isto.

46 SR-AJ-837-KPR, II-3-c-2/64, Informacija Saveznog sekretarijata za unutrašnje poslove o narušavanju javnog reda i mira prilikom obustava rada u nekim radnim organizacijama (23. 6. 1969.).

47 SR-AJ-507-CK SKJ, IV/73, Stenografske beleške sa 11. sednice Izvršnog biroa Predsedništva SKJ održane 15. 6. 1969.

48 SR-AJ-837-KPR, II-3-c-2/64, Štampa o obustavama rada u Jugoslaviji. 
su do smjene staroga direktora i postavljanja novog. On je od radničkoga savjeta isposlovao veću slobodu da bi se primjenom odgovarajućih restriktivnih mjera što prije konsolidiralo poslovanje. U prvoj polovini godine radnički savjet ratificirao je niz mjera poput umanjenja zarada, naknade za prekovremeni rad i bolovanje, koje su najteže pogodile proizvodne radnike. ${ }^{49}$ Ta rezanja novčanih davanja smanjila su njihov životni standard za čitavih 30\%. Time su ionako teški životni uvjeti lučkih radnika dodatno pogoršani s obzirom na to da su „mnogi radnici sa porodicama” stanovali „u bunkerima, štalama, napuštenim autobusima i drugim mestima” koja su, prema ocjeni sindikata, bila „neshvatljiva za vreme u kome živimo i nespojiva sa našim socijalističkim društvom". ${ }^{50}$ Samo dan prije nego što su donesene mjere trebale stupiti na snagu radnički savjet donio je nove, kojima su planirane dodatne uštede, prije svega u domeni zaštite na radu, stambene politike i obuke radnika. Ne mareći mnogo za (ne)raspoloženje u poduzeću, članovi radničkoga savjeta, ponosni na donesene mjere štednje, organizirali su banket i „zbog dobro obavljenog posla” financijski nagradili četiri svoja predstavnika bonusom u visini prosječne dvomjesečne plaće radnika na doku. ${ }^{51}$ Okolnost da se o tako važnim mjerama odlučivalo bez njihova znanja i diskusije pred čitavim kolektivom ${ }^{52}$, mimo dotadašnje samoupravne prakse, još više je učvrstila dio radnika u stavu da se izlaz iz takve, za njih nepodnošljive, ekonomske situacije može naći isključivo štrajkom. Tako se i na primjeru poduzeća „Luka” još jednom pokazao raskorak između onoga što samoupravljanje jest i onoga što bi trebalo biti. $^{53}$

Je li početkom 1969. bilo moguće anticipirati da se nezadovoljstvo sve više širi u pojedinim tvornicama, da može prerasti u svojevrsni bunt i stvoriti, za jednu socijalističku zemlju, veoma neugodne probleme, teško je reći na osnovi raspoloživih izvora. Iako su bili uvod u prosvjed širih razmjera, ispod partijskoga radara prošla su četiri manja štrajka u riječkoj luci krajem $1968 .{ }^{54}$ i nekoliko kraćih prekida rada u Industriji motora u Rakovici u proljeće 1969. godine. ${ }^{55}$ Usprkos tome što je bilo dobro poznato da je „u luci bilo stalno problema”, „nije bilo ni jednom ozbiljno signalizirano kakva je situacija i kako se ona razvija" ${ }^{56}$, pa je štrajk iznenadio sve instance vlasti. Rad je obustavljen u nedjelju 1. lipnja na inicijativu 10 do 15 radnika $^{57}$ nezadovoljnih odlukama radničkoga savjeta donesenim dva dana prije. ${ }^{58}$ Iako je čitava nedjeljna smjena

49 SHABAD, „Strikes in Yugoslavia: Implications for Industrial Democracy”, 301.

50 POPOV, „Štrajkovi u savremenom jugoslovenskom društvu”, 609.

51 SHABAD, „Strikes in Yugoslavia: Implications for Industrial Democracy”, 301.

52 POPOV, „Štrajkovi u savremenom jugoslovenskom društvu”, 609; SHABAD, „Strikes in Yugoslavia: Implications for Industrial Democracy”, 301.

53 ŽUPANOV, „Samoupravna radna organizacija. Ideal i stvarnost u svjetlosti jedne organizacione teorije", 15-16.

54 „Štrajk i samoupravljanje”, Borba, 27. 9. 1969.

55 MUSIĆ, Making and Breaking the Yugoslav Working Class, 45.

56 SR-AJ-837-KPR, II-4-a/70, Štrajk u Riječkoj luci i luci Ploče (1. - 5. 6. 1969.).

57 SR-AJ-837-KPR, II-4-a/70, Informacija o događajima u Riječkoj luci.

58 „Štrajk koji se zastideo. Šta se stvarno desilo u Rijeci”, NIN (Beograd), 29. 6. 1969. 
prekinula posao, ništa nije upućivalo na to da će već sutradan nezadovoljstvo prerasti u otvoreni revolt, a zatim i u svojevrsni linč. Rano ujutro 2. lipnja 800 radnika prve i treće smjene stupilo je u štrajk, a nešto kasnije na dva dana rad je obustavilo oko 4500 ljudi. Prema informacijama koje je dostavio Savezni sekretarijat za unutarnje poslove, oko 150 radnika, umjesto da idu na dokove, okupilo se oko upravne zgrade. Njih dvadesetak fizički je napalo generalnoga i komercijalnoga direktora i nanijelo im „teže telesne povrede”. ${ }^{59}$ Manja grupa bijesnih radnika izvodila je iz ureda jednoga po jednog zaposlenog, gurajući ih u masu okupljenu pred vratima. Tamo su ih „dočekivale šake sa svih strana”, a radnici koji su pokušavali zaštititi napadnute također su dobili batina. ${ }^{60}$ Tom prilikom napadnuti su šef računovodstva, šef zajedničkih službi, analitičar, direktor sektora za ekonomiku i predsjednik sindikalne podružnice, koji su lakše ozlijeđeni. ${ }^{61}$ Nezadovoljstvo se za tili čas prelilo izvan kruga luke, a revoltirani štrajkaši neke od rukovodilaca naganjali su po ulicama grada i tukli. ${ }^{62}$ Najgore je ipak prošao generalni direktor, koji se pokušao skloniti u hotel, „ali ga je grupa gnevnih ljudi pronašla i fizički napala pred očima jedne italijanske delegacije". ${ }^{63}$

U prvom trenutku čelnici Centralnoga komiteta Saveza komunista Hrvatske vjerovali su da se ne radi samo o izljevu radničkoga nezadovoljstva, nego da događaji u Rijeci imaju veze s „nekim ekstremnim elementima u Beogradu" s obzirom na to da su izbili na godišnjicu studentskih demonstracija. ${ }^{64}$ Iako je veoma brzo ustanovljeno da je riječ o međusobno nepovezanim događanjima, ostao je strah da bi se lučkim radnicima mogli pridružiti studenti, ali i zaposleni u drugim poduzećima koja su bila u još težem ekonomskom položaju. Milicija je izvedena na ulice, ali je zauzet stav da ne poduzimaju nikakve posebne mjere osim da blokiraju dio luke u kojem su se nalazili štrajkaši. ${ }^{65}$ Iza kordona milicije koji je čuvao pristup luci i priječio izlazak radnika u grad okupilo se oko 2500 građana koji su bodrili štrajkaše i „podsticali ih na obračunavanje". ${ }^{66}$ Prema službenim izvještajima, dio radnika bacao je razne predmete na milicajce, pa su oni upotrijebili silu i intervenirali pendrecima,

59 SR-AJ-837-KPR, II-3-c-2/64, Informacija Saveznog sekretarijata za unutrašnje poslove o narušavanju javnog reda i mira prilikom obustava rada u nekim radnim organizacijama (23. 6. 1969.); JOVANOV, Radnički štrajkovi u SFRJ od 1958. do 1969., 107; DOBRIVOJEVIĆ TOMIĆ, „Harbingers of Crisis. Labor Strikes in Yugoslavia (1958-1974)”, 171.

60 SR-AJ-837-KPR, II-3-c-2/64, Štampa o obustavama rada u Jugoslaviji.

61 SR-AJ-837-KPR, II-3-c-2/64, Informacija Saveznog sekretarijata za unutrašnje poslove o narušavanju javnog reda i mira prilikom obustava rada u nekim radnim organizacijama (23. 6. 1969.).

62 POPOV, „Štrajkovi u savremenom jugoslovenskom društvu”, 609; SIRC, The Yugoslav Economy under Self-Management, 195.

63 SR-AJ-837-KPR, II-3-c-2/64, Stampa o obustavama rada u Jugoslaviji.

64 SR-AJ-837-KPR, II-4-a/70, Prekid rada lučkih radnika na Rijeci (2. 6. 1969.).

65 DOBRIVOJEVIĆ TOMIĆ, „Harbingers of Crisis. Labor Strikes in Yugoslavia (19581974)", 172.

66 SR-AJ-507- CK SKJ, IV/75, Informacije o obustavama rada (27. 6. 1969.). 
„nakon čega se veliki dio povukao” ${ }^{67}$ Vlasti su procjenjivale da najmilitantniji dio zaposlenih čine „pijani i polupijani bukači”68, ali i naglašavale da se oko luke okupio dio građana, a da među njima ima „ološa” i „pijanica”. ${ }^{69}$ O stupnju eskalacije štrajka i mogućnosti da se potpuno izgubi kontrola nad situacijom svjedoči i izvještaj Savke Dabčević-Kučar, u to vrijeme predsjednice Izvršnoga vijeća Sabora Socijalističke Republike Hrvatske. „Politička je ocjena da to nije bio štrajk nego pobuna u najgorem vidu sa siledžijskim nastupom jedne grupe koja se služila najgrubljim sredstvima. Generalni direktor je tako pretučen da je još u šoku, a ostale rukovodioce jurili su ulicama kao zvjeri. Njihov nastup je bio takav da su se i radnici morali suprotstaviti njihovoj razbijačkoj djelatnosti i zaprijetiti im da će se sa njima obračunati ako pokušaju da razbijaju objekte." ${ }^{70}$ Osjećaj nelagode zbog neočekivanih nemira produbljivala je prisutnost stranih brodova u luci. Vlasti su se, čini se, pribojavale da bi događanja u Rijeci mogla narušiti imidž zemlje u inozemstvu s obzirom na to da su stranci snimali neugodne scene radničkoga nezadovoljstva. ${ }^{71}$

Suočeni s radničkim buntom, jugoslavenski rukovodioci priznavali su da je sanacijski program „možda prenaglo donesen” i da situacija ne bi na taj način eskalirala da su problemi rješavani sukcesivno. ${ }^{72}$ Međutim, po izbijanju štrajka događaje je bilo teško kontrolirati ili brzo zaustaviti. Atmosfera je postajala zategnutija iz sata u sat, formiran je štrajkaški odbor, a rukovodiocima poduzeća zabranjen je ulazak u krug „Luke”. Vođe štrajka uputili su organima samoupravljanja svoju listu zahtjeva, koja se svodila na odustajanje od svih restriktivnih mjera i vraćanje na stanje iz 1968. godine. ${ }^{73}$ Vlasti su učinile sve da prekinu štrajk i makar privremeno otklone radničko nezadovoljstvo. Budući da uprava poduzeća i predsjednica općinske skupštine Neda Andrić nisu uspjeli postići nikakav dogovor s radnicima, vrlo brzo postalo je jasno da organi samoupravljanja de facto više ne postoje i da se ne može ništa drugo nego nastojati da se prosvjed ne proširi. ${ }^{74}$ Organizatori štrajka u prvi mah pristajali su samo na pregovore s republičkim funkcionarima ${ }^{75}$, pa su se potpredsjednik Republičkoga izvršnog vijeća Dušan Dragosavac i potpredsjednik Republičkoga odbora Sindikata odmah zaputili u Rijeku. ${ }^{76}$ Iako je upravni odbor odbio štrajkaške zahtjeve, ne bi li se izbjegli daljnji sukobi, ali i sve veći financijski gubici uslijed prekida rada u najvažnijoj jugoslavenskoj luci, ipak je došlo do

67 DOBRIVOJEVIĆ TOMIĆ, „Harbingers of Crisis. Labor Strikes in Yugoslavia (19581974)", 172.

68 SR-AJ-837-KPR, II-4-a/70, Rijeka, 16:40 časova.

69 SR-AJ-837-KPR, II-4-a/70, Informacija o događajima u Riječkoj luci.

70 SR-AJ-837-KPR, II-4-a/70, Bez naslova, 4. 6. 1969.

71 SR-AJ-507- CK SKJ, IV/75, Informacije o obustavama rada (27. 6. 1969.).

72 SR-AJ-837-KPR, II-4-a/70, Informacija o događajima u Riječkoj luci.

73 „Štrajk i samoupravljanje”, Borba, 27. 9. 1969.

74 SR-AJ-837-KPR, II-4-a/70, Štrajk u Riječkoj luci i luci Ploče (1. - 5. 6. 1969.).

75 SR-AJ-837-KPR, II-4-a/70, Prekid rada lučkih radnika na Rijeci.

76 DOBRIVOJEVIĆ TOMIĆ, „Harbingers of Crisis. Labor Strikes in Yugoslavia (19581974)", 171-172. 
sporazuma. ${ }^{77}$ Vraćen je na snagu stari cjenovnik lučkih radova, naknada za prijevozne troškove za dolazak i odlazak s posla ostala je kao prije, kao i naknada za godišnji odmor. Ukinuta je i odredba pravilnika kojom je bio umanjen iznos naknade za vrijeme bolovanja ${ }^{78}$, a radnici su se obvezali da će, kako bi nadoknadili izgubljeno, raditi i nedjeljom. ${ }^{79}$ Potrebna sredstva osigurana su zaduživanjem poduzeća kod poslovne banke. ${ }^{80}$ Zaposleni označeni kao kolovođe prosvjeda morali su snositi i zakonske konsekvencije. Kaznene prijave podnesene su protiv 20 ljudi, istrage otvorene protiv 14, a šest osoba zadržano je u pritvoru. ${ }^{81}$ Općinska skupština Rijeke postavila je prinudnu upravu u luci ${ }^{82}$, a Javnom tužilaštvu povjereno je da ispita čitav slučaj ne bi li se utvrdilo „šta i ko stoji iza svega toga” ${ }^{83}$ Međutim, svjesni da je i nakon smirivanja štrajka situacija nestabilna, republičke vlasti strahovale su od izbijanja novih nemira. „Posle obustave postoji osećaj nesigurnosti kod rukovodećeg kadra i šire u preduzeću", konstatirano je u jednom od izvještaja. ${ }^{84}$ Stoga je u Rijeku kao pojačanje upućeno 130 milicajaca iz Zagreba, Karlovca i Pule. ${ }^{85}$

\section{Strukturni uzroci problema i njihove posljedice}

Iako se, gledano na kratke staze, činilo da radnici mogu biti zadovoljni postignutim dogovorom, vlasti su bile svjesne da se svi olako dani ustupci „neće moći ispuniti” i da je pitanje trenutka kad će potisnuto nezadovoljstvo ponovo izazvati štrajk ili neki sličan protest. ${ }^{86}$ Nakon dogovora sa štrajkašima Savka Dabčević-Kučar opisala je situaciju u luci sljedećim riječima: „Glava je u zavoju, ali je potrebno liječenje." ${ }^{87}$ Nagomilani problemi bili su prije svega strukturne prirode. Usprkos dobrom geografskom položaju i povezanosti s razvijenim Podunavljem ${ }^{88}$, sistem rada u luci i promjena poslovanja uvjetova-

77 „Štrajk i samoupravljanje”, Borba, 27. 9. 1969.

78 „Radnici Riječke luke nastavili rad”, Borba, 4. 6. 1969.

79 SR-AJ-837-KPR, II-4-a/70, Štrajk u Riječkoj luci i luci Ploče (1. - 5. 6. 1969.).

80 „Štrajk i samoupravljanje”, Borba, 27. 9. 1969.

81 SR-AJ-837-KPR, II-3-c-2/64, Informacija Saveznog sekretarijata za unutrašnje poslove o narušavanju javnog reda i mira prilikom obustava rada u nekim radnim organizacijama (23. 6. 1969.).

82 SR-AJ-837-KPR, II-4-a/70, Situacija na Rijeci, 3. 6. u 14:00 časova. Na osnovi izvora koji se čuvaju u Arhivu Jugoslavije nemoguće je reći što se dalje događalo u poduzeću „Luka” i kad je ponovo uvedeno samoupravljanje. Naime, zbog sve veće decentralizacije zemlje, poduzeća poput „Luke” privlačila su pozornost saveznih organa uglavnom u slučajevima velikih kriza.

83 SR-AJ-837-KPR, II-4-a/70, Bez naslova, 4. 6. 1969.

84 SR-AJ-507-CK SKJ, IV/75, Informacije o obustavama rada (27. 6. 1969.).

85 DOBRIVOJEVIĆ TOMIĆ, „Harbingers of Crisis. Labor Strikes in Yugoslavia (19581974)", 172

86 SR-AJ-507- CK SKJ, IV/75, Stenografske beleške sa 13. sednice Izvršnog biroa Predsedništva SKJ održane 1. 7. 1969.

87 SR-AJ-837-KPR, II-4-a/70, Dokument bez naslova, 4. 6. 1969.

88 Rijeka nije bila samo najvažnija luka u Jugoslaviji nego i važna tranzitna luka za Austriju, Mađarsku i Čehoslovačku; STRAŽIČIĆ, „Rijeka - vodeća hrvatska luka”, 40. 
na privrednom reformom iz 1965., ali i oštra konkurencija zbog predimenzioniranja lučkih kapaciteta u zemlji, odražavali su se na financijsko-ekonomske rezultate toga poduzeća. ${ }^{89} \mathrm{Na}$ tehničku zaostalost, koja se ogledala u zastarjelosti skladišnoga prostora i lučkih dizalica ${ }^{90}$, nadovezivala se loša obrazovna struktura radnika. Od 4500 zaposlenih njih čak 728 bilo je bez završene osnovne škole, a $80 \%$ činili su nekvalificirani i polukvalificirani radnici. Neki od njih bili su prisiljeni doslovno prenositi teret na vlastitim leđima, pa su ozljede na radu bile česte, a broj invalida o kojima se poduzeće staralo velik. ${ }^{91}$ Kvalifikacijska struktura radnika bila je jedan od osnovnih uzroka velike fluktuacije ${ }^{92}$, a nepromišljeno zapošljavanje rezultiralo je viškom radne snage, prije svega administrativnih službenika. O ozbiljnosti situacije rječito svjedoči podatak da čak 180 osoba nije bilo raspoređeno na radna mjesta, a dio radnika je „samo formalno zauzimao” određene pozicije. Razlike u plaćama između nekvalificiranih i kvalificiranih radnika bile su male, pa su stručnjaci, nezadovoljni radnim uvjetima, masovno napuštali luku. Neriješeni problemi su se gomilali, nezadovoljstvo radnika je raslo, a ideje o reorganizaciji poduzeća nailazile su na otpore. Tražeći pomoć, uprava poduzeća obraćala se tijekom 1968. općinskim, republičkim i saveznim organima, poslovnim bankama i Saveznoj privrednoj komori. Kako pozitivnoga odgovora na iznesene zahtjeve nije bilo ${ }^{93}$, izlaz iz nastalih teškoća tražio se u programu mjera koji je obuhvaćao uzimanje sanacijskoga kredita za pokrivanje gubitaka, zahtjev općinskim vlastima za smanjenje doprinosa na gradsko zemljište, molbu Republičkom sekretarijatu za privredu za ukidanje kamate na poslovni fond te vraćanje amortizacije na minimum. Zaustavljeno je zapošljavanje novih radnika i doneseni su novi pravilnici, kojima su umanjena primanja i naknade radnika. ${ }^{94}$ Sve napore za konsolidaciju luke Rijeka zaustavio je štrajk, pa je gubitak od 12 milijuna dinara napravljen 1968. narastao za novih 600.000.95

$\mathrm{Na}$ nabrojene probleme nadovezivali su se i oni koji su pritiskali sve jugoslavenske luke, a posebno Rijeku kao najvažniju. ${ }^{96}$ Stoga istinske uzroke štrajka treba tražiti u nedefiniranoj lučkoj politici na saveznoj razini ${ }^{97}$, sta-

89 SR-AJ-130-SIV, 728-1184, Ekonomsko-tehničko stanje preduzeća „Luka” Rijeka (27. 6. 1969.).

90 SR-AJ-130-SIV, 728-1184, Mjere investicionog karaktera za racionalizaciju rada u Luci Rijeka (lipanj 1969.).

91 „Posle obustave rada u lukama Rijeka i Ploče. Luke bez dovoljno brodova”, Politika (Beograd), 10. 6. 1969.

${ }_{92}$ SR-AJ-130-SIV, 728-1184, Poduzeće „Luka” Rijeka - Ekonomsko-tehničko stanje.

93 SR-AJ-130-SIV, 728-1184, Oslobađanje od plaćanja kamata na poslovni fond.

94 SR-AJ-507- CK SKJ, IV/75, Informacije o obustavama rada (27. 6. 1969.).

95 „Posle obustave rada u lukama Rijeka i Ploče. Luke bez dovoljno brodova”, Politika, 10. 6. 1969.

96 Kroz riječku luku tijekom čitavoga perioda postojanja socijalističke Jugoslavije prolazilo je 40-60\% ukupnoga lučkog prometa. SIĆ, „Suvremene tendencije razvoja riječke luke s posebnim osvrtom na lučko-industrijske funkcije Bakarskog zaljeva”, 56. O razvoju luke u Rijeci vidi: STRAŽIČIĆ, „Rijeka - vodeća hrvatska luka”, 37-46; LE NORMAND, „Rijeka as a Socialist Port: Insight from Jugolinija’s Early Years, 1947-1960", 193-198.

97 SR-AJ-837-KPR, II-4-a/70, Informacija o događajima u Riječkoj luci. 
gnantnom ukupnom prometu roba, iako su kapaciteti luka rasli, smanjenim prihodima, zaoštravanju konkurencije, lošoj organizaciji rada i slaboj mehaniziranosti. Težak ekonomski položaj u kojem su se krajem 60-ih godina našle sve jugoslavenske luke (Kopar, Pula, Rijeka, Zadar, Šibenik, Split, Metković, Ploče, Dubrovnik i Bar) bio je posljedica ekstenzivnoga investiranja, pri čemu „nije poštovan osnovni ekonomski princip racionalnosti i efikasnosti ulaganja”, nego je izgradnjom većega broja „svaštarskih luka vođena politika rasparčavanja" ionako male količine jugoslavenskoga morskog prometa. ${ }^{98}$ Naime, tijekom Drugoga svjetskog rata sve jugoslavenske luke pretrpjele su velika razaranja. Nove vlasti uspjele su ih obnoviti do 1951., a već 1952. započeti i izgradnju dviju novih luka u Pločama i Baru, čija je lokacija određena na završnim točkama dviju novoprojektiranih glavnih pruga: Sarajevo - Ploče i Beograd - Bar. Investiranje u izgradnju novih luka nastavljeno je 1958., kad je počela izgradnja Kopra, a kasnije je u Zadru djelomično završena nova luka Gaženica, koja je bila manjega kapaciteta. Međutim, osim nekoliko modernijih pogona, veći dio lučke tehničke opreme u jugoslavenskim lukama bio je zastario. Loša tehnička opremljenost onemogućavala je moderniziranje rada, ubrzavanje lučkih operacija, skraćivanje boravka brodova u lukama i uštede koje je na taj način bilo moguće ostvariti. ${ }^{99}$ Zanemarivanje tranzitnoga prometa i razvoja industrije na obalnom području, zatvorenost jugoslavenskih luka u pogledu privredne i financijske suradnje s domaćim i inozemnim partnerima i sve oštrija konkurencija među svjetskim lukama bili su samo neki od faktora koji su onemogućavali rentabilno poslovanje. Činilo se da se jugoslavenske luke nalaze u začaranom krugu iz kojega je bilo gotovo nemoguće izaći. Tehnička modernizacija bila je neophodna, ali i neizvediva bez uzimanja kredita, čija je otplata opterećivala već ionako narušene financije i tjerala poduzeća u sve veće gubitke. ${ }^{100} \mathrm{U}$ ukupnom kreditnom zaduženju svih jugoslavenskih luka udio Rijeke bio je čak 28\%. ${ }^{101}$ Samo su rate za komercijal-

98 SR-AJ-130-SIV, 728-1184, Ekonomski položaj morskih luka - prijedlozi mera (15. 7. 1969.). Međutim, Savezni sekretarijat za privredu nije se složio s tom ocjenom Izvršnoga vijeća Sabora Socijalističke Republike Hrvatske. Iako je konstatirano da bi „koncentracija lučkog prometa u dve ili tri luke dovela te luke u izuzetno povoljan, čak i monopolistički položaj”, u analizi položaja luka koju je načinio Savezni sekretarijat za privredu tvrdi se da „uzroke gubitaka koji se pojavljuju u poslednje dve godine, i to samo u nekim lukama, ne treba tražiti u rešenjima donetim pre dvadeset godina i situaciji stvorenoj pre deset godina". Priznavalo se, međutim, da „investicije u nove objekte nisu uvek bile racionalno usmerene, kako usled potpunog odsustva koordinacije na tom polju između luka i investiranja u objekte kakvi su u drugim lukama već postojali i bili dovoljni za sadašnji nivo prometa, tako i usled nedostatka deviznih sredstava za nabavku specijalne lučke mehanizacije”. SR-AJ-130-SIV, 728-1184, Ekonomski položaj morskih luka (27. 1. 1970.). Vidi i: „Posle obustave rada u lukama Rijeka i Ploče. Luke bez dovoljno brodova", Politika, 10. 6. 1969.

99 SR-AJ-130-SIV, 728-1184, Ekonomski položaj morskih luka (27. 1. 1970.).

100 SR-AJ-130-SIV, 728-1184, Ekonomski položaj morskih luka - prijedlozi mera (15. 7. 1969.); SR-AJ-130-SIV, 728-1184, Ekonomski položaj morskih luka (27. 1. 1970.).

101 SR-AJ-130-SIV, 728-1184, Mjere investicionog karaktera za racionalizaciju rada u Luci Rijeka (lipanj 1969.). 
ne kredite za izgradnju luke za rasute terete u Bakru i nabavku tegljača koje su dospijevale 1969. prelazile cijeli iznos gubitka iz prethodne godine i bilo ih je „nemoguće pokriti prihodima tih kapaciteta” koji su bili „iskorišćeni samo u manjem procentu”. ${ }^{102}$ Uprava poduzeća pravdala je prezaduženost „neravnopravnim položajem u sistemu kreditiranja” budući da je proširivanje kapaciteta bilo financirano uzimanjem (nepovoljnih) komercijalnih kredita, dok su druge luke u tu svrhu dobivale bespovratna sredstva od države. ${ }^{103}$

Pristajanje na sve zahtjeve štrajkaša u cilju sprečavanja novih gubitaka poduzeća i širenja nezadovoljstva ubrzo je došlo na naplatu. Visina financijskih izdataka potrebnih za uvećane plaće, saniranje negativne bilance poslovanja i otplatu kredita prelazila je ekonomske mogućnosti općinskih, a djelomično i republičkih vlasti. Poput domino-efekta, pritisak da se novčano pomogne u konsolidaciji posrnule luke širio se od nižih instanci k višima. Poduzeće se za pomoć obraćalo Općini, Općina Izvršnom vijeću Sabora Socijalističke Republike Hrvatske, a oni Saveznom izvršnom vijeću. Financijski nemoćna iz svoje blagajne pokriti obećana davanja, općinska skupština zaključila je da od Izvršnoga vijeća Hrvatske treba tražiti da bespovratno osigura sanaciju gubitaka iz 1968. i 37 milijuna dinara na ime naknade za uvećane plaće. Od Saveznoga izvršnog vijeća trebalo je tražiti da se komercijalni kredit podignut za izgradnju luke Bakar u visini od 75 milijuna dinara „preuzme na teret državnog kapitala a time da se dosadašnje obaveze prema Luci konvertiraju na dugoročni zajam sa rokom otplate od 30 godina”. ${ }^{104} \mathrm{Na}$ štrajk u Rijeci nadovezao se onaj u luci Ploče ${ }^{105}$, pa je Izvršno vijeće Hrvatske predložilo Saboru da donese odluku o odgađanju plaćanja anuiteta za sve luke u ovoj republici, ali i da zatraži pomoć Federacije. ${ }^{106}$ Razmatrajući zahtjeve Izvršnoga vijeća Hrvatske, Savezni sekretarijat za privredu odbio je zahtjev da se luke oslobode plaćanja kamata na poslovni fond i da im se odgodi plaćanje po zajmovima iz Općega investicionog fonda. Molba da se utječe na poslovne banke da olakšaju privređivanje lukama morala je biti odbijena s obzirom na zakonske ovlasti Saveznoga izvršnog vijeća. Međutim, Savezni sekretarijat za privredu ostavio je prostor za djelomično ispunjavanje toga zahtjeva. Naime, zauzelo se stajalište da bi Savezno izvršno vijeće moglo preporučiti poslovnim bankama da preispitaju uvjete kredita koje su odobrile lukama i da, u granicama svojih

102 SR-AJ-130-SIV, 728-1184, Ekonomski položaj morskih luka (27. 1. 1970.).

103 SR-AJ-130-SIV, 728-1184, Traži se otpis kredita (16. 7. 1969.); SR-AJ-130-SIV, 728-1184, Oslobađanje od plaćanja kamata na poslovni fond (16. 7. 1969.).

104 SR-AJ-507- CK SKJ, IV/75, Informacije o obustavama rada (27. 6. 1969.).

105 Štrajk u luci Ploče počeo je 4. lipnja 1969., odmah po okončanju prekida rada u Rijeci. Intervenirala je Služba javne sigurnosti u „cilju sprečavanja rušenja trafostanice i međusobnog fizičkog obračunavanja radnika". Trojica organizatora su privedena. Protiv četiri osobe podnesene su kaznene prijave, a protiv njih sedam prekršajne. SR-AJ-837-KPR, II-3-c-2/64, Informacija Saveznog sekretarijata za unutrašnje poslove o narušavanju javnog reda i mira prilikom obustava rada u nekim radnim organizacijama (23. 6. 1969.).

106 SR-AJ-130-SIV, 728-1184, Ekonomski položaj morskih luka - prijedlozi mera (15. 7. 1969.). 
mogućnosti, nađu rješenja koja bi olakšala velike kreditne obveze tih poduzeća. Međutim, da bi se problemi luka dugoročno riješili, bilo je potrebno, prema mišljenju Sekretarijata, „u okviru samoupravnog dogovora između preduzeća” izraditi koncepciju dugoročnoga razvoja cjelokupnoga jugoslavenskoga lučkog sistema i svake luke posebno, prije svega u periodu 1971. - 1975., a zatim i do 1982. godine..$^{107}$

\section{Epilog}

I pet godina nakon privredne reforme 1965. jugoslavenska ekonomija bila je opterećena starim problemima. Stopa rasta industrijske proizvodnje i poljoprivredne proizvodnje prepolovljena je u odnosu na razdoblje 1952. - 1964. Jugoslavija je sve više zaostajala za ekonomski razvijenim državama budući da je brzina stope razvoja sredinom 60-ih godina pala ispod svjetskoga prosjeka. I u samoj zemlji povećavao se jaz između razvijenih i nerazvijenih regija. Od 1965. došlo je do usporavanja produktivnosti rada i pada u efikasnosti investiranja. Gubici poduzeća su rasli, a broj nezaposlenih bivao je sve veći. Da bi se sačuvao standard, cijene su zamrznute na početku reforme (1965.), a zatim i 1970. godine. Tijekom 1969. i 1970. privredni rast održavan je na račun zaduživanja u inozemstvu i inflacije, što se odražavalo na standard svih zaposlenih, a posebno onih s niskim primanjima. ${ }^{108}$ Iako se provođenje reforme, počevši od 1965., udaljavalo od njezinih intencija, na partijskim savjetovanjima funkcionari su neprestano referirali „da stvari idu u redu, da se reforma izvršava” ${ }^{109}$ Plaće su povećavane iznad ekonomskih mogućnosti, što je poskupljivalo proizvodnju i izazivalo rast maloprodajnih cijena. Novac je iz profitabilnih poduzeća prelijevan u nerentabilna da bi se sanirali gubici. Suvišni radnici zadržavani su na poslu, a ako je otpuštanja i bilo, ona su uglavnom pogađala zaposlene u proizvodnji. Industrijski kapaciteti bili su u mnogim sektorima predimenzionirani, a gradnja novih postrojenja skupa i duga, pa se događalo da i najopremljenije poduzeće „bude zastarelo po merilima razvijenih zemalja”. ${ }^{110}$ Uvoz je rastao brže od izvoza, pa je, po riječima Branka Horvata, mišljenje da je jugoslavenska privreda krajem 60-ih godina bila intenzivnija i više otvorena prema inozemstvu bila „iluzija”. ${ }^{111}$

$\mathrm{Na}$ ekonomsku krizu, sve veću društvenu podvojenost i veliko socijalno raslojavanje radnici su odgovarali štrajkovima. Politika prekomjernoga i lakomislenoga investiranja u tešku industriju, nepotrebno dupliranje kapaciteta, velika izdvajanja za plaće, ali i zapošljavanje nekvalificirane radne snage, posebno izraženo do sredine 50-ih godina prošloga stoljeća, dolazili su na naplatu. Štrajk u poduzeću „Luka” u lipnju 1969. bio je svojevrsna paradigma

\footnotetext{
107 SR-AJ-130-SIV, 728-1184, Ekonomski položaj morskih luka (27. 1. 1970.).

108 SR-AJ-837-KPR, II-3-c-2/81, Stabilizacija i intenzifikacija privređivanja.

109 HORVAT, Jugoslavenska privreda 1965-1983, 168.

110 SR-AJ-837-KPR, II-3-c-2/81, Stabilizacija i intenzifikacija privređivanja.

111 HORVAT, Jugoslavenska privreda 1965-1983, 172.
} 
jugoslavenskih ekonomskih problema za koje, pokazat će se, trajnoga i dugoročnoga rješenja nije bilo. Strahujući od nemira širih razmjera, a poučene iskustvom studentskih prosvjeda iz 1968., vlasti su pristale na ustupke ne bi li barem privremeno suzbile nezadovoljstvo. Na temelju raspoloživih izvora stječe se dojam da je mnogo više od nedefinirane lučke politike na saveznoj razini i stagnantnoga prometa robe, usprkos rastu kapaciteta jugoslavenskih luka, vlasti zabrinjavao izlazak radnika na ulice i prisutnost stranih brodova u luci. Situacija iz Rijeke ponovila se dvije godine poslije u Kopru, kad je štrajk prerastao $\mathrm{u}$,agresivne demonstracije” $\mathrm{u}$ kojima su nezadovoljni radnici napustili luku i zauzeli javni prostor u središtu grada. ${ }^{112}$ Čini se da su iz tih nasilnih događaja, netipičnih za jugoslavenski socijalizam, izvjesne pouke izvukle i vlasti i lučki radnici. Prilikom sljedećega velikoga (četverodnevnog) štrajka koji je izbio u riječkoj luci u lipnju 1971., usprkos masovnom sudjelovanju radnika, tenzija i nemilih scena nije bilo. Pregovori između štrajkaša i radničkoga savjeta od početka su vođeni mirnim tonom i u „poslovnom maniru”. I dok su 1969. vlasti pokušale spriječiti riječki Novi list da izvijesti o štrajku ${ }^{113}$, u lipnju 1971. izvještavanje glasila "bilo je objektivno i točno”. ${ }^{114}$ Međutim, događaji u riječkoj luci i štrajkovi u drugim jugoslavenskim poduzećima 70ih godina i kasnije pokazali su i sve mane radničkoga samoupravljanja. $\mathrm{Na}$ radničke savjete menadžment poduzeća mogao je lako utjecati, a sami radnici bili su prije svega zainteresirani za povećanje plaće, a ne i za korištenje profita u cilju povećanja produktivnosti, tim prije što je veća produktivnost značila i smanjenje broja radnih mjesta. ${ }^{115}$

Do 1970. postalo je jasno da je reforma neuspješna. Stabilizacijski program Saveznoga izvršnog vijeća i Rezolucija Savezne skupštine o osnovama društveno-ekonomske politike u 1971. predvidjeli su moderniziranje, prestrukturiranje i jačanje konkurentnih sposobnosti jugoslavenske privrede, ali i poboljšanje razine stručnosti zaposlenih. ${ }^{116}$ Početkom desetljeća životni standard bio je u padu, pa su radnici pokušavali, i uglavnom uspijevali, preko štrajka natjerati vlasti na financijske ustupke. Partijsko i sindikalno rukovodstvo bilo je svjesno da su „ekonomski i socijalni problemi mnogo teži i složeniji, a raspoloženje radnika mnogo ozbiljnije" nego što to statistički podaci o štrajkovima sugeriraju. Priznavalo se da „ima slučajeva da su zahtevi za većim i sigurnijim" plaćama opravdani, ali da materijalne mogućnosti poduzeća ne dopuštaju povišice. ${ }^{117}$ Pokazalo se da socijalizam radnicima nije mogao osigurati jednakost. Razlike između republika i pokrajina, ali i proizvodnih

112 RUTAR, „Containing Conflict and Enforcing Consent in Titoist Yugoslavia: The 1970 Dockworkers' Strike in Koper (Slovenia)", 279.

${ }_{113}$ MIHALJEVIĆ, Komunizam i čovjek, 512.

114 ANTIĆ, „Dockers' Strike Successful in Yugoslav Port of Rijeka”.

115 KREMPTON, Balkan posle Drugog svetskog rata, 206.

116 SR-AJ-837-KPR, II-3-c-2/81, Stabilizacija i intenzifikacija privređivanja.

117 SR-AJ-837-KPR, II-3-c-2/104, Informacija o obustavama rada u Jugoslaviji od 1. januara do 1 . juna 1973 (6. 6. 1973.). 
grana, rasle su umjesto da se smanjuju. ${ }^{118}$ Iako je Ustavom iz 1974. i Zakonom o udruženom radu sva ekonomska i politička vlast bila formalno dodijeljena radnicima, partijska su rukovodstva nakon političke krize „preuzela sve poslove upravljanja društvom, ne ostavljajući gotovo nikakav prostor za demokratsku proceduru u radu samoupravnih organa”. ${ }^{119}$ Posljedica politike investiranja koja se kosila s „ekonomskim razumom” ${ }^{120}$ bio je vrtoglavi rast vanjskoga duga. ${ }^{121}$ Zaduživanje i ulaganje dovelo je i do povećanja standarda, pa je realna vrijednost zarade u drugoj polovini 70 -ih godina bila najveća u jugoslavenskoj povijesti. ${ }^{122}$ Lakomisleno vođena ekonomska politika stigla je na naplatu već početkom 80 -ih. Radnici su pokušavali popraviti svoj materijalni i ekonomski položaj štrajkovima, pa je broj štrajkaša 1988. bio 28,5 puta veći nego 1980. godine. Međutim, sa sve većom demokratizacijom društva i odumiranjem institucija, koje je lagano zahvaćalo sve društvene instance, smanjivali su se interesi vlasti da se štrajkovi okončaju što prije. Omasovljavanje radničkih prosvjeda stoga nije doprinijelo njihovoj većoj efikasnosti budući da su zahtjevi štrajkaša 60-ih i u prvoj polovini 70 -ih ispunjavani i preko svih mogućnosti, a 80 -ih se izlazilo ususret samo zahtjevima onih radnika koji su bili važni za sustav. ${ }^{123}$

\section{Zaključak}

Od prvoga štrajka, koji je izbio u siječnju 1958. u rudniku Trbovlje, do sredine 1969. u Jugoslaviji je, prema nepotpunim statističkim podacima, organizirano ukupno 1800 štrajkova, u kojima je sudjelovalo oko sto tisuća radnika. Kašnjenje plaća, kriteriji za raspodjelu osobnih dohodaka koji su favorizirali administrativne službe i loš socijalno-ekonomski položaj nekvalificiranih i polukvalificiranih radnika bili su neki od osnovnih uzročnika nezadovoljstva u jugoslavenskim poduzećima. Štrajkovi kao oblik pritiska na vlasti davali su rezultate. Nagomilani problemi, barem na kratke staze, ekspresno su rješavani budući da su nadležni bili spremni ići mnogo iznad financijskih mogućnosti poduzeća ne bi li radnike vratili na posao. Godine 1969. Jugoslaviju su potresla tri velika radnička štrajka, od kojih je najozbiljniji izbio u lipnju u poduzeću „Luka” u Rijeci. Taj štrajk bio je svojevrsna paradigma jugoslavenskih ekonomskih problema za koje, pokazat će se, trajnoga i dugoročnoga rješenja nije bilo.

${ }_{118}$ JOVIĆ, Jugoslavija. Država koja je odumrla, 251.

119 BILANDŽIĆ, Historija Socijalističke Federativne Republike Jugoslavije, 446-448. Vidi i: ARCHER, MUSIĆ, „Approaching the Socialist Factory and its Workforce: Considerations from Fieldwork in (former) Yugoslavia", 48.

${ }^{120}$ BILANDŽIĆ, Historija Socijalističke Federativne Republike Jugoslavije, 449.

${ }_{121}$ DUDA, Pronadeno blagostanje, 28; ČALIĆ, Istorija Jugoslavije u 20. veku, 315.

122 DUDA, Pronadeno blagostanje, 28.

${ }^{123}$ DOBRIVOJEVIĆ TOMIĆ, „Harbingers of Crisis. Labor Strikes in Yugoslavia (19581974)”, 172-173. Vidi i: MARKOVIĆ, „Radnički štrajkovi u socijalističkom i tranzicionom društvu Jugoslavije i Srbije”, 55-56; NOVAKOVIĆ, Propadanje radničke klase, 126. 
Usprkos dobrom geografskom položaju i povezanosti s razvijenim Podunavljem, sustav rada u riječkoj luci i promjena poslovanja uvjetovana privrednom reformom iz 1965., ali i oštra konkurencija zbog predimenzioniranja lučkih kapaciteta u zemlji, odražavali su se na financijsko-ekonomske rezultate toga poduzeća. Tehnička zaostalost, loša kvalifikacijska struktura zaposlenih i veliki viškovi administrativnih radnika bili su samo neki od problema koji su opterećivali luku. Tražeći pomoć, uprava poduzeća obraćala se tijekom 1968. općinskim, republičkim i saveznim organima, poslovnim bankama i Saveznoj privrednoj komori. Kako pozitivnoga odgovora na iznesene zahtjeve nije bilo, izlaz iz nastalih teškoća tražio se u programu sanacijskih mjera koje su dodatno snizile životni standard zaposlenih. Iako je neposredni okidač za izbijanje štrajka bilo umanjenje plaća, naknada za prekovremeni rad i bolovanje, njegove istinske uzroke trebalo je tražiti u nedefiniranoj lučkoj politici na saveznoj razini, stagnantnom ukupnom prometu roba, iako su kapaciteti luka rasli, smanjenim prihodima, zaoštravanju konkurencije, lošoj organizaciji rada i slaboj mehaniziranosti. Težak ekonomski položaj u kojem su se krajem 60 -ih godina našle sve jugoslavenske luke bio je posljedica ekstenzivnoga investiranja koje je dovelo do usitnjavanja ionako male količine jugoslavenskoga morskog prometa.

Rad je obustavljen u nedjelju 1. lipnja 1969. na inicijativu 10 do 15 radnika. Iako je cijela nedjeljna smjena prekinula posao, ništa nije upućivalo na to da će već sutradan nezadovoljstvo prerasti u otvoreni revolt, a zatim i u svojevrsni linč u kojem su ozlijeđeni generalni i komercijalni direktor, šef računovodstva, šef zajedničkih službi, analitičar, direktor sektora za ekonomiku i predsjednik sindikalne podružnice. Na ulice je izvedena milicija, a vlasti su učinile sve da prekinu štrajk i makar privremeno otklone radničko nezadovoljstvo. Vraćen je na snagu stari cjenovnik lučkih radova, a naknada za prijevozne troškove za dolazak i odlazak s posla i za godišnji odmor ostala je kao prije. Ukinuta je i odredba pravilnika kojom je bio umanjen iznos naknade za vrijeme bolovanja, a radnici su se obvezali da će raditi i nedjeljom kako bi nadoknadili izgubljeno. Međutim, svota koju je trebalo izdvojiti za uvećanje plaća, saniranje negativne bilance poslovanja i namirivanje kreditnih obveza prelazila je mogućnosti ne samo općinskih nego djelomično i republičkih vlasti. Stoga se Općina obratila za pomoć Izvršnom vijeću Sabora Socijalističke Republike Hrvatske, a oni Saveznom izvršnom vijeću. No Savezni sekretarijat za privredu zauzeo je stajalište da je probleme jugoslavenskih luka moguće riješiti samo ako se izradi koncepcija dugoročnoga razvoja cjelokupnoga jugoslavenskoga lučkog sistema i svake luke posebno, prije svega u periodu 1971. - 1975., a zatim i do 1982. godine.

\section{Arhivski i neobjavljeni izvori}

SR-AJ-130-SIV: Srbija, Arhiv Jugoslavije, Beograd, fond 130, Savezno izvršno veće.

SR-AJ-507-CK SKJ: Srbija, Arhiv Jugoslavije, Beograd, fond 507, Centralni komitet Saveza komunista Jugoslavije. 
SR-AJ-142-SSRNJ: Srbija, Arhiv Jugoslavije, Beograd, fond 142, Socijalistički savez radnog naroda Jugoslavije

SR-AJ-837-KPR: Srbija, Arhiv Jugoslavije, Beograd, fond 837, Kabinet predsednika Republike.

SR-AJ-117-CVSSJ: Srbija, Arhiv Jugoslavije, Beograd, fond 117, Centralno veće Saveza sindikata Jugoslavije

ANTIĆ, Zdenko. „Dockers' Strike Successful in Yugoslav Port of Rijeka”, 16. 7. 1971. OSA catalog. Pristup ostvaren 15. 9. 2021. https://catalog.osaarchivum.org/catalog/osa:6b9c33cf-aa04-4f1a-b963-082475403cf0.

\section{Periodika}

Borba (Beograd), 1969.

NIN (Beograd), 1969.

Politika (Beograd), 1969.

\section{Literatura}

ARCHER, Rory; MUSIĆ, Goran. „Approaching the Socialist Factory and its Workforce: Considerations from Fieldwork in (former) Yugoslavia”. Labor History 58 (2017), br. 1: 44-66.

ARZENŠEK, Vladimir. „Otuđenje i štrajk”. Revija za sociologiju 6 (1976), br. 2-3: 3-16.

BILANDŽIĆ, Dušan. Historija Socijalističke Federativne Republike Jugoslavije. Glavni procesi 1918-1985. Zagreb: Školska knjiga, 1985.

ČALIĆ, Mari Žanin. Istorija Jugoslavije u 20. veku. Beograd: Clio, 2013.

DOBRIVOJEVIĆ TOMIĆ, Ivana. „Harbingers of Crisis. Labor Strikes in Yugoslavia (1958-1974)”. Istorija 20. veka (2019), br. 1: 161-174.

DUDA, Igor. Pronađeno blagostanje. Svakodnevni život i potrošačka kultura u Hrvatskoj 1970-ih i 1980-ih. Zagreb: Srednja Europa, 2010.

DUDA, Igor. „Tehnika narodu! Trajna dobra, potrošnja i slobodno vrijeme u socijalističkoj Hrvatskoj”. Časopis za suvremenu povijest 37 (2005), br. 2: 371-392.

HORVAT, Branko. Jugoslavenska privreda 1965-1983. Prognoze i kritike. Ljubljana; Zagreb: Cankarjeva založba, 1984.

HORVAT, Branko. Privredni sistem i ekonomska politika Jugoslavije. Problemi, teorije, ostvarenja, propusti. Beograd: Institut ekonomskih nauka, 1970.

HYDER, Patrick. Bought and Sold. Living and Loosing the Good Life in Socialist Yugoslavia. Ithaca; London: Cornell University Press, 2011.

JOVANOV, Neca. Radnički štrajkovi u SFRJ od 1958. do 1969. Beograd: Zapis, 1979.

JOVIĆ, Dejan. Jugoslavija. Država koja je odumrla. Zagreb: Prometej, 2003. 
KREMPTON, Ričard. Balkan posle Drugog svetskog rata. Beograd: Clio, 2003.

LE NORMAND, Brigitte. „Rijeka as a Socialist Port: Insight from Jugolinija's Early Years, 1947-1960". The International Journal of Maritime History 33 (2021), br. 1: 193-208.

LUTHAR, Breda. „Remembering socialism: On desire, consumption and surveillance”. Journal of Consumer Culture 6 (2006), br. 2: 229-259.

MARKOVIĆ, Predrag. Beograd između Istoka i Zapada. Beograd: Službeni list SRJ, 1996.

MARKOVIĆ, Predrag. „Radnički štrajkovi u socijalističkom i tranzicionom društvu Jugoslavije i Srbije”. Tokovi istorije (2014), br. 1: 53-74.

MIHALJEVIĆ, Josip. Komunizam i čovjek. Odnos vlasti i pojedinca u Hrvatskoj od 1958. do 1972. godine. Zagreb: Hrvatski institut za povijest, 2016.

MUSIĆ, Goran. Making and Breaking the Yugoslav Working Class. The Story of Two Self-Managed Factories. Budapest: CEU Press, 2021.

NOVAKOVIĆ, Nada. Propadanje radničke klase. Materijalni i društveni položaj radničke klase Jugoslavije od 1960. do 1990. godine. Beograd: Rad, 2007.

POPOV, Nebojša. „Štrajkovi u savremenom jugoslovenskom društvu”. Sociologija: časopis za sociologiju, socijalnu psihologiju i socijalnu antropologiju XI (1969), br. 4: 605-631.

RADELIĆ, Zdenko. „Prvi štrajkovi u socijalističkoj Jugoslaviji (Dokumenti iz 1945. godine)". Časopis za suvremenu povijest 20 (1988), br. 3: 123-139.

RUTAR, Sabine. „Containing Conflict and Enforcing Consent in Titoist Yugoslavia: The 1970 Dockworkers' Strike in Koper (Slovenia)". European History Quarterly 45 (2015), br. 2: 275-294.

SHABAD, Goldie. „Strikes in Yugoslavia: Implications for Industrial Democracy”. British Journal of Political Science 10 (1980), br. 3: 293-315.

SIĆ, Miroslav. „Suvremene tendencije razvoja riječke luke s posebnim osvrtom na lučko-industrijske funkcije Bakarskog zaljeva”. Radovi: glasilo Geografskog odjela PMF-a Sveučilišta u Zagrebu 17-18 (1982/1983), br. 1: 55-66.

SIRC, Ljubo. The Yugoslav Economy under Self-Management. London: The Macmillan Press, 1979.

STRAŽIČIĆ, Nikola. „Rijeka - vodeća hrvatska luka”. Geografski glasnik 55 (1993): 37-46.

UNKOVSKI-KORICA, Vladimir. The Economic Struggle for Power in Tito's Yugoslavia. From World War II to Non-Alignment. London: I. B. Taurus, 2016.

ŽUPANOV, Josip. „Industrijski konflikti i samoupravni sistem”. Revija za sociologiju 1 (1971), br. 1: 5-24.

ŽUPANOV, Josip. „Samoupravna radna organizacija. Ideal i stvarnost u svjetlosti jedne organizacione teorije". Revija za sociologiju 4 (1974), br. 4: 15-26. 


\section{SUMMARY}

\section{The Price of Reckless Investment: The strike in the Port of Rijeka in 1969 and its Consequences}

Despite its good geographical position and connections with the developed Danube region, the system of work in the Port of Rijeka and the changes conditioned by the economic reform and the fierce competition influenced by the oversizing of port capacities in the country affected the financial and economic results of this company. Technical backwardness, the poor qualification structure of employees, and large redundancies of administrative workers were just some of the problems that burdened the port. Asking for help, in 1968 the company's management turned to municipal, republican, and federal bodies, commercial banks, and the Chamber of Commerce. As there was no positive response to the stated requests, a way out of the difficulties was sought in a programme of economic measures that further lowered the living standard of employees. Dissatisfied workers responded to the austerity measures with a strike. Work was suspended on Sunday, 1 June 1969, at the initiative of 10 to 15 workers. Although the entire weekly shift ceased working, there was no indication that the dissatisfaction would turn into an open revolt, and then into a riot in which the general and commercial directors, chief accountant, analyst, director of economics, and president of the trade union were injured. The police took to the streets, and the authorities did everything to end the strike and at least temporarily eliminate the workers' dissatisfaction. The austerity measures were abandoned, and the workers promised to work on Sundays in order to make up for what they had lost. Those employees who were considered the leaders of the protest had to bear the legal consequences. Criminal charges were filed against 20 people, investigations were opened against 14, and six people were detained.

Key words: strike; Port of Rijeka; 1969; Yugoslavia; League of Communists of Yugoslavia 